\title{
Macro and Micro Nutrient Supply to Soil and Plants from Sugar Mill Mud
}

\author{
Ishrat Jahan Sanchary' ${ }^{1}$ Kazi Md. Jahangir Kabir ${ }^{1}$, Shah Muhammad Imamul Huq,3* \\ ${ }^{1}$ Department of Soil and Environmental Sciences, University of Barishal, Barishal, Bangladesh \\ ${ }^{2}$ Department of Soil, Water and Environment, University of Dhaka, Dhaka, Bangladesh \\ ${ }^{3}$ Vice Chancellor, University of Barishal, Barishal, Bangladesh \\ Email: ijsanchary@gmail.com, jahangirswed@gmail.com, *imamhuq@hotmail.com
}

How to cite this paper: Sanchary, I.J. Kabir, K.Md.J. and Huq, S.M.I. (2019) Macro and Micro Nutrient Supply to Soil and Plants from Sugar Mill Mud. Agricultural Sciences, 10, 164-172.

https://doi.org/10.4236/as.2019.102014

Received: December 30, 2018

Accepted: February 23, 2019

Published: February 26, 2019

Copyright () 2019 by author(s) and Scientific Research Publishing Inc. This work is licensed under the Creative Commons Attribution International License (CC BY 4.0).

http://creativecommons.org/licenses/by/4.0/

\begin{abstract}
The effects of sugar mill mud application on the availability of nutrients for plant uptake were investigated. Mill mud generated from conventional sugar mill operations was applied in three different rates and a leafy vegetable, locally called "PuiShak" or Indian spinach (Basellarubra L.) was grown for 60 days as a test crop in a pot culture experiment. Crop yield and essential nutrients like $\mathrm{N}, \mathrm{P}, \mathrm{K}$ and $\mathrm{Zn}$ uptake concentration was determined to come up with an inference that higher doses of mill mud application impose better effect on root and shoot uptake of these elements. A little infraction was observed for nitrogen uptake by plants for the maximum dose.
\end{abstract}

\section{Keywords}

Nutrient Supply, Soil-Plant System, Mill Mud

\section{Introduction}

Sugarcanes are used for sugar production mainly. But sugars can be made from sugar beets also. Approximately $70 \%$ of total white crystal sugar comes from sugarcane and 30\% from sugar beets. Sugarcane growing countries of the world are lying between the latitude $36.7^{\circ}$ north and $31.0^{\circ}$ south of the equator extending from tropical to subtropical zones [1]. Sugarcane occupies an area of about 27 million hectares in the world [2].

Thousands of industries or sugar mills have been built up depending on the produced sugarcanes which generate millions of tons of by-products or wastes. Molasses and bagasse (the remaining fibrous solids) produced from sugar mills, are inputs for generating heat in other industries. Bagasse are burned for fuel in the mill's steam boilers, which makes the mill more than energy self-sufficient 
and the surplus bagasse goes to animal feed, to paper manufacture, or to generate electricity for sale. Thus, the by-products are also used for different purposes. Bangladesh now produces about 150,000 tons of sugar, 100,000 tons of molasses and 800,000 tons of bagasse per year. The country, however, ranks the lowest in the world in per acre yield of sugarcane-only 15 tons [3]

Besides the stated uses, sugar mill wastes can also be used in agricultural fields. Sugar mill wastes like filter press mud, fly ash and boiler ash are evidenced to be recommended as limes in soils to raise soil $\mathrm{pH}$. Along with increasing organic matter content, it is evidenced to increase microbial activity also [4]. Mudpress or filter cake has a great potential to supply nutrients as well as to affect the physico-chemical and biological properties of soil [5]. Boiler or bagasse ash was advised to be used as fertilizer due to high content of potassium [6] and as liming material due to its high $\mathrm{pH}$ [7]. All three types of sugar mill wastes are evidenced to have significant amount of silicon also [4].

The present study was aimed to assess the efficiency of sugar mill mud to supply essential macro and micro nutrient elements to plants for their growth. A simple pot experiment was conducted to demonstrate the value of recycling these waste products back onto soils and "Puishak" or Indian spinach (Basellarubra L.), a leafy vegetable, was grown as a test crop.

\section{Materials and Methods}

The following steps and procedures were followed to conduct this experiment.

\subsection{Soil Sample Collection and Preparation}

Soil sample was collected around Barishal University area. A portion of the soil was air dried, visible debris were removed, crushed and screened through a 5 $\mathrm{mm}$ sieve to grow crops. The other portion was sieved with a $0.5 \mathrm{~mm}$ sieve and used for background analysis of the soil.

\subsection{Soil Sample Analysis}

Soil sample was analyzed to know background information of some physical, chemical and physic-chemical parameters. The soil had a $\mathrm{pH}$ of 6.92 , silt loam texture, $0.93 \%$ organic carbon, $0.18 \%$ total nitrogen, $0.10 \mathrm{meq} \%$ available potassium and $2.13 \mathrm{mg}$ available phosphorus/kg soil.

\subsection{Mill Mud Collection and Preparation}

Sugar mill mud was collected from Faridpur Sugar mill. The wet raw sample was then left to air drying for 7 days and visible debris were removed. The dried sample was then crushed and screened through $0.5 \mathrm{~mm}$ sieve.

\subsection{Pot Preparation and Plant Growth}

Three different doses of mill mud were selected to apply in soils with a control treatment and there was a triplicate of each treatment. There were a total of 12 
different pots for all the treatments and $2 \mathrm{~kg}$ of $5 \mathrm{~mm}$ sieved soil sample was taken in each pot. Inorganic fertilizers like Urea, TSP and MoP were added to each pot as recommended in the Fertilizer Recommendation Guide [8] of Bangladesh. Then the prepared mill mud samples were added at the rate of $25 \mathrm{~g} / \mathrm{kg}$ soil (pot: SMM-1), $50 \mathrm{~g} / \mathrm{kg}$ soil (pot: SMM-2) and $100 \mathrm{~g}$ mill mud/kg soil (pot: SMM-3); and no mill mud sample was added to the control pot. The pots were kept moistened for next 15 days. After 15 days of addition of mill mud, plant seeds were sown. As an experimental plant, a local leafy vegetable called "PuiShak" (Basellarubra L.) was selected as it is fast growing. Plants were allowed to grow for 2 months in the pots.

\subsection{Plant Analysis after Harvest}

After the vegetative stage, plants were uprooted from the soils. The harvested plants, especially plant roots were washed first with tap water and then again with distilled water and then wiped with blotting paper to absorb extra water from the plants. The plants were cut into two pieces to divide into root and shoot parts. The fresh weight of the collected plant samples was noted. The samples were first air-dried and then oven-dried. The dry weight of the collected plant samples were also noted after oven-drying. The plant samples were ground and sieved through a $0.2 \mathrm{~mm}$ sieve and preserved in plastic containers for further chemical analysis.

\section{Chemical Analysis of Soil and Plant Samples}

To gather information about the background nutrient content of soil and to analyze plant soils after harvesting, the following nutrients were analyzed.

\subsection{Total Nitrogen}

Total nitrogen of the samples was determined by Kjeldahl's method following concentrated Sulfuric acid $\left(\mathrm{H}_{2} \mathrm{SO}_{4}\right)$ digestion [9]. The distillation of the digested samples was done with $40 \% \mathrm{NaOH}$ and the distillates were collected on a $2 \%$ Boric acid mixed indicator. The distillates were titrated against Sulfuric acid $\left(\mathrm{H}_{2} \mathrm{SO}_{4}\right)$.

\subsection{Total and Available Phosphorus}

The available phosphorus of soil was determined by Ascorbic acid blue color method to know the initial content of $\mathrm{P}$ in soil.

The total contents of $\mathrm{P}$ of the plant samples were determined by yellow color method in a spectrophotometer after the extract were collected by digesting the plant samples with nitric acid $\left(\mathrm{HNO}_{3}\right)$ as described [10].

\subsection{Total and Extractable Potassium}

Extractable $\mathrm{K}$ content of soil was determined using flame photometer and MoP fertilizer was recommended on the basis of the initial $\mathrm{K}$ content of the soil. 
The total potassium contents in plant samples were determined by the nitric acid $\left(\mathrm{HNO}_{3}\right)$ digestion method. After digestion, the amount of total potassium was estimated by flame photometer [9].

\subsection{Total Zinc}

The total $\mathrm{Zn}$ contents of the plant samples were measured by atomic absorption spectrophotometer (AAS) at $535 \mathrm{~nm}$ after digesting with nitric acid $\left(\mathrm{HNO}_{3}\right)$ [10].

\subsection{Statistical Analysis}

A one-way ANOVA was conducted to see the differences for groups with different treatments in each case of root and shoot. Least significant differences (LSD) post hoc multiple comparison test was done to check the significant differences among the individual treatment groups. P-value was set at $<0.05$ level. SPSS 25.0 was used for statistical analysis.

\section{Results and Discussion}

The yield of "puishak" in fresh and dry weight basis as affected by the different doses of mill mud treatments are shown in Figure 1. The values presented in the figure averages of three individual replications. There were 5 plants in each pot and the results presented here are in $\mathrm{g} / 100$ plant basis.

The better vegetative growth in shoots as fresh and dry weight basis was recorded for the treatment SMM-1 whereas better root growth in fresh and dry weight basis was recorded for SMM-2 treatment. In the case of plant roots, fresh weight for SMM-1 and SMM-2 treatment was increased significantly in comparison with the control one whereas the highest dose, SMM-3, did not show any significant result. But Figure 2 reveals that, the dry weight of the roots of the plants was found to be not significant while compared with the control treatment except the SMM-2 treatment.

Though it is clear from this experiment that the yield of "pui shak" was measured to be highest for SMM-1 treatment and was found to be decreased gradually with the increase of the dose; an opposite pattern was evidenced for sugarcane

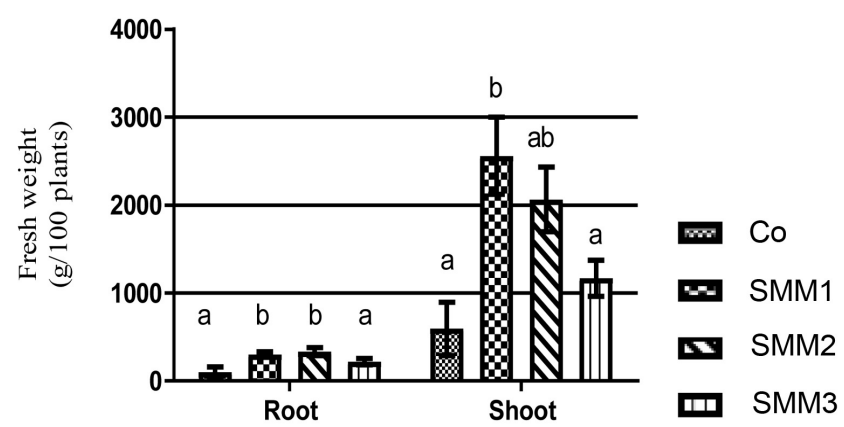

Figure 1. Fresh weight of plant root and shoot in g/100 plants basis at different doses of mill mud application. 


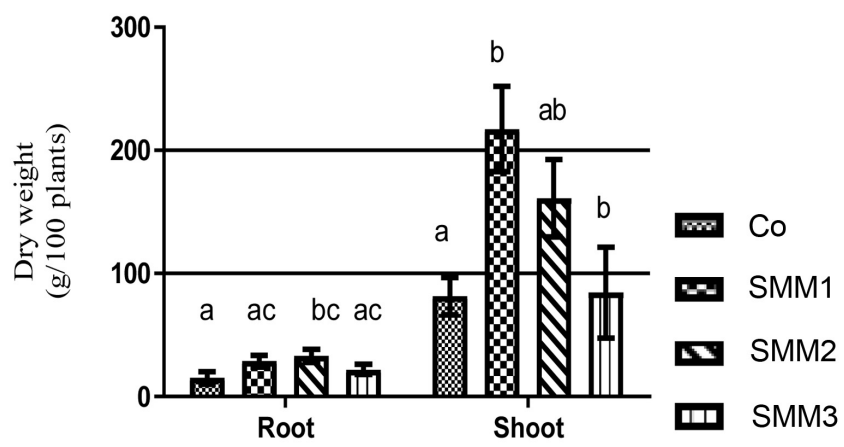

Figure 2. Dry weight of plant root and shoot in g/100 plants basis at different doses of mill mud application.

yield production using mudpress in the cane field [11]. Similarly, it was also reported that the yield of sugar cane yield was recorded to be increased with the increased dose of mudpress application [12]. The production of fulvic acid might have been increased with increased production of organic matter from the higher doses of sugar mill mud which helped in solubilizing essential nutrients. But the nutrients might not be taken up by the plant roots rather be uptaken by the organisms present in the root zone of the soil. Plant roots might fail to compete with the organisms in uptaking nutrients from the soil.

Unlike the pattern, root height of the plants was found to be not significant except for the SMM-3 treatment (Figure 3). The maximum length of the roots was also recorded for the highest dose.

A very different pattern was observed for the height of the shoot part of the plants. Shoot height was found to be increased with the increase of rate of mill mud applied. In this figure, it is clear that the height increased for SMM-2 and SMM-3 treatment was significant to the height of plants for control one. But the height for SMM-1 treatment was to be not significant (P value 0.059$)$ to higher doses of mill mud.

As nutrient elements, total nitrogen, phosphorus, zinc and potassium were analyzed in plant root and shoot samples. In the root sample of plants, the total content of $\mathrm{N}$ was found to be highest for SMM-2 treatment which was significantly higher than both the control (P value 0.000$)$ and SMM-1 treatment (P value 0.003 ) (Figure 4 ). The mineralization and mobilization might have been increased with which helped in accumulation of more N. Nitrogen accumulation was found to be increased with increased dose of mill mud application, similar finding was also noted [13], though the content of total $\mathrm{N}$ was decreased a little for the highest treatment and the decrease was statistically not significant. They measured Partial Factor Productivity (PFP), Agronomic Efficiency (AE), Apparent Recovery Efficiency (ARE) and Physiological Efficiency (PE) among the indices of $\mathrm{N}$ use efficiency using the following formulas [14]:

Partial factor productivity $(\mathrm{PFP})=\mathrm{kg}$ crop yield $/ \mathrm{kg}$ nutrient applied

Agronomic efficiency $(\mathrm{AE})=\mathrm{kg}$ crop yield increase $/ \mathrm{kg}$ nutrient applied

Apparent recovery efficiency $(\mathrm{RE})=\mathrm{kg}$ nutrient taken up/kg nutrient applied

Physiological efficiency $(\mathrm{PE})=\mathrm{kg}$ yield increase $/ \mathrm{kg}$ nutrient taken up 


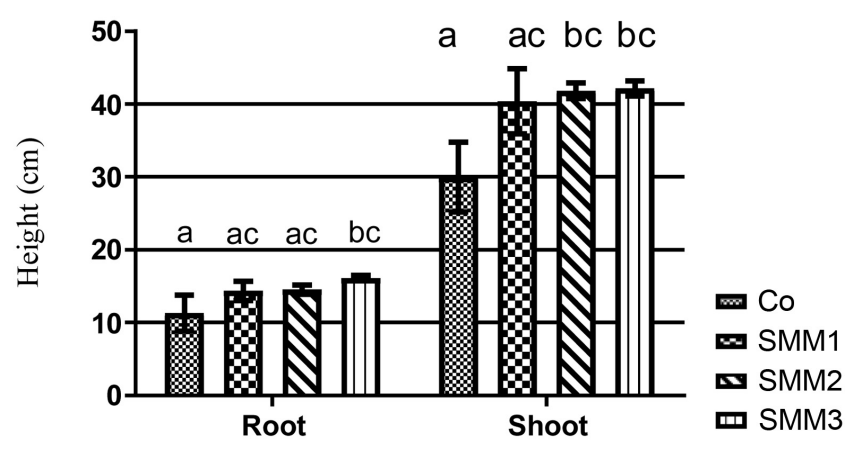

Figure 3. Root and shoot height $(\mathrm{cm})$ of plants at different doses of mill mud application.

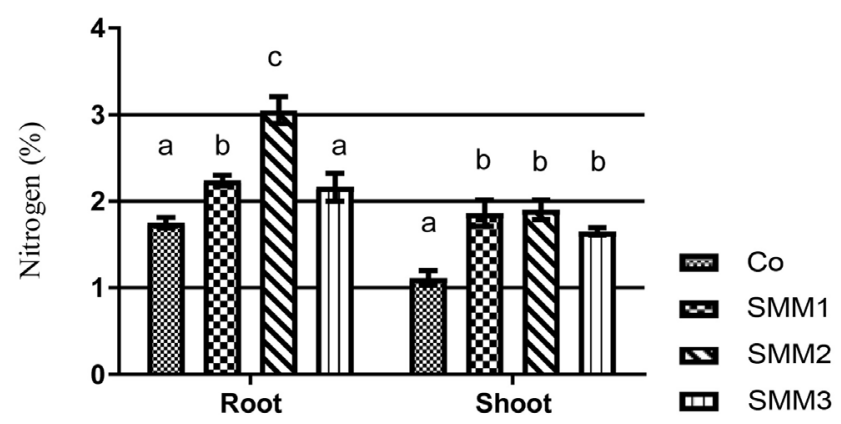

Figure 4. Root and shoot N (\%) content of plants at different doses mill mud application.

Similar to the pattern of nitrogen uptake, maximum total $\mathrm{P}$ content in the plant root was observed for SMM-2 treatment and this value is significant to rest of the treatments (Figure 5). It can be predicted from Figure 6 and Figure 7 that, total content of basic cations like $\mathrm{K}$ and $\mathrm{Zn}$ increase significantly with increasing doses. SMM-3 treatment was highly significant to the control treatment for both $\mathrm{K}$ and $\mathrm{Zn}$ where $\mathrm{P}$ value was calculated as 0.001 and 0.047 respectively. Correspondingly, it was also stated that application of sugar mill waste, fly ash, resulted in additions of basic cations, $\mathrm{P}$ and $\mathrm{Si}$ [4].

For shoot content of these elements, all the mentioned nutrients show more or less a similar pattern. Total $\mathrm{N}$ content in shoot part of the plants was increased significantly with the application of mill mud, than the control treatment, where the highest concentration was recorded for SMM-2 treatment (Figure 4). But total $\mathrm{N}$ content for the highest dose was surprisingly decreased. The decrease might be associated with the increase in $\mathrm{CO}_{2}$ evolution and thus microbial activity. This suggests that relatively greater microbial immobilization of $\mathrm{N}$ occurred at the high rates of waste addition as was observed by [4].

On the other hand, it is apparent from (Figures 5-7) that the shoot content of total $\mathrm{P}$ was highest for SMM-1 treatment whereas total $\mathrm{K}$ and $\mathrm{Zn}$ content was maximum for SMM-3 treatment. Though there was increase or decrease in the total content of these elements in the shoot parts of the plants, statistically those changes were found to be not significant to each other. 


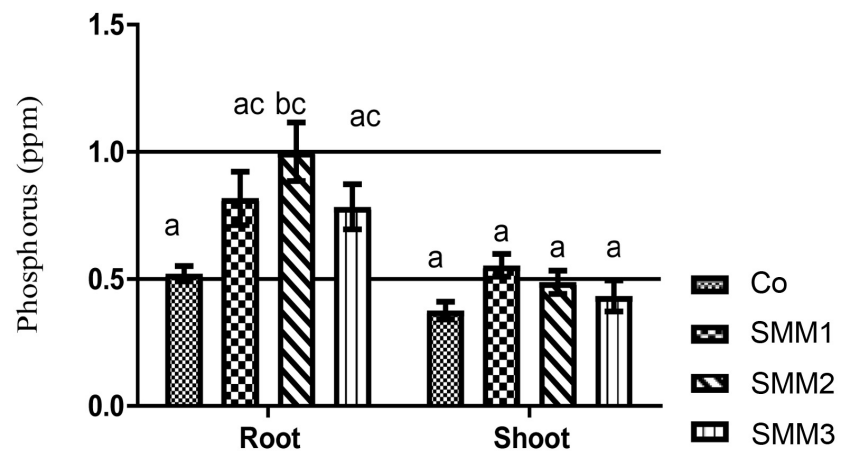

Figure 5. Root and shoot P (ppm) content of plants at different doses mill mud application.

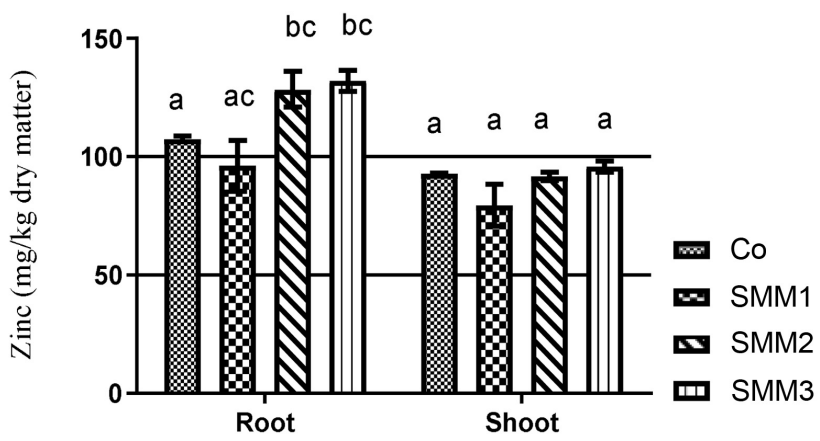

Figure 6. Root and shoot $\mathrm{Zn}(\mathrm{ppm})$ content of plants at different doses mill mud application.

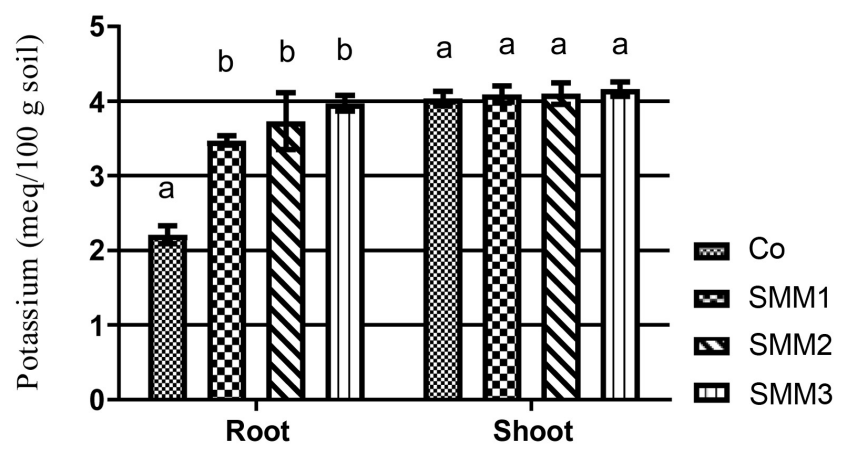

Figure 7. Root and shoot K (meq/100g soil) content of plants at different doses mill mud application.

\section{Conclusions}

The findings of this study elucidate that application of higher doses of processed sugar mill mud causes additions of basic cations, like $\mathrm{K}$ and $\mathrm{Zn}$ to the soil which can later be taken up by plants. On the other hand, application of sugar mill mud at $50 \mathrm{~g} / \mathrm{kg}$ soil rate can be concluded as more effective for additions of $\mathrm{N}$ and $\mathrm{P}$ to the soil and growing plants. Its application will surely enhance the organic matter level also. Since loss of soil organic matter is a common phenomenon for agricultural lands, this practice is believed to improve crop productivity of soils in a sustainable and efficient manner. 
Though mill mud is evidenced to improve soil fertility, it should be kept in mind that, this can have the potential to cause accumulation of excess levels of certain elements like, B, Mo, S and Se; which can create toxicity in soils and can be proved to be harmful for plant growth. Accumulation of these elements needs to be monitored in a regular interval.

\section{Acknowledgements}

The pot experiment as well as the laboratory analysis of this study was conducted in the Department of Soil and Environmental Sciences, University of Barishal, Bangladesh. I also acknowledge the University of Barishal for providing the financial grant to conduct the research.

\section{Conflicts of Interest}

The authors declare no conflicts of interest regarding the publication of this paper.

\section{References}

[1] http://www.sugarcanecrop.com/introduction/

[2] Heinrichs, R., Otto, R., Magalhães, A. and Meirelles, G.C. (2017) Importance of Sugarcane in Brazilian and World Bioeconomy. In: Dabbert S., Lewandowski, I., Weiss, J. and Pyka, A., Eds., Knowledge-Driven Developments in the Bioeconomy. Economic Complexity and Evolution, Springer, Cham, 205-217. https://doi.org/10.1007/978-3-319-58374-7_11

[3] http://en.banglapedia.org/index.php?title=Sugar_Industry

[4] Dee, B.M., Haynes, R.J. and Meyer, J.H. (2002) Sugar Mill Wastes Can Be Important Soil Amendments. Proceedings of the South African Sugar Technologists' Association, 76, 51-60.

[5] Shankaraiah, C. and Murthy, K.N.K. (2005) Effect of Enriched Pressmud Cake on Growth, Yield and Quality of Sugarcane. Sugar Tech, 7, 1-4. https://doi.org/10.1007/BF02942519

[6] Cosico, W.C. (1985) Organic Fertilizers: Their Nature, Properties and Use. Framing Systems and Soil Resources Institute, UPLB, Laguna, 136 p.

[7] Vance, E.D. (1996) Land Application of Wood-Fired and Combination Boiler Ashes: An Overview. Journal of Environment Quality, 25, 937-944. https://doi.org/10.2134/jeq1996.00472425002500050002x

[8] BARC (Bangladesh Agricultural Research Council) (2005) Fertilizer Recommendation Guide-(2005). BARC Soils Publication No. 45. BARC, Dhaka, 1-254.

[9] Jackson, M.L. (1965) Soil Chemistry Analysis. Prentice-Hall, Ing. Pub. Madison, Wisconsin, 183-192.

[10] Imamul Huq, S.M. and Alam, M.D. (2005) A Handbook on Analyses of Soil, Plant and Water. Bangladesh Australia Centre for Environmental Research (BACER), University of Dhaka, Bangladesh, 1-246.

[11] Bangar, K.S., Parmar, B.B. and Maini, A. (2000) Effect of Nitrogen and Press Mud Application on Yield and Uptake of N, P and K by Sugarcane (Saccharum officinarum L.). Crop Research, 19, 198-203. 
[12] Tiwari, R.J. and Nema, G.K. (1999) Response of Sugarcane (Saccharum officinarum) to Direct and Residual Effect of Pressmud and Nitrogen. Indian Journal of Agricultural Sciences, 69, 644-647.

[13] Sarimong, R.T., Sanchez, P.B., Badayos, R.B., Paterno, E.S. and Sta. Cruz, P.C. (2017) Effect of Organic Amendments and Microbial Inoculant on Nitrogen, Phosphorus and Potassium Use Efficiency of Sugarcane under Acid Typic Hapludand. Journal of International Society for Southeast Asian Agricultural Sciences, 23, 114-124.

[14] Mosier, A.R., Syers, J.K. and Freney, J.R. (2004) Agriculture and the Nitrogen Cycle. Assessing the Impacts of Fertilizer Use on Food Production and the Environment. Scientific Committee on Problems of the Environment (Scope-65). Island Press, London. 